\title{
PROVISÓRIOS A CHAVE DO SUCESSO
}

Emerson GASPERIN, Carolina GARCIA, João Paulo MANFRINATO

A prótese fixa provisória tem a finalidade de servir como referencial para o planejamento e confecção da prótese definitiva. Portanto, é imprescindível a elaboração de próteses provisórias com a mesma seriedade, atenção e diligência com que se trabalham as próteses definitivas, elaborando as mesmas características de alta qualidade e recuperação da estética. As restaurações provisórias desempenham um papel relevante na saúde periodontal, quer na fase de tratamento, quer na fase de manutenção de saúde obtida. Os contornos cervicais obtidos com acuidade juntamente com ótimo acabamento final com superfícies de textura lisa, permitem a manutenção da saúde periodontal e preservam a posição da margem gengival até a colocação da prótese definitiva. O desempenho do espaço interproximal de forma piramidal, estabelecendo as relações de contato, sem invadir a área da papila, possibilita a manutenção de sua integridade e impede a migração dos dentes pilares e evita a impacção alimentar. Na medida em que a estética e a fonética permitem ameias amplas, alem de facilitar o controle de placa, evitam a formação de uma área de col e dão condições para que se forme um epitélio ceratinizado desejável. Este trabalho visa apresentar e demonstrar passo-apasso a confecção de provisórios de alta qualidade.

Palavras-chave: Prótese dentária; Planejamento; Estética. 